\title{
Occurrence of squamous cell carcinoma in Milchschaf sheep in Uruguay
}

\author{
Juan Agustín García ${ }^{1 *}$ Carina Quinteros ${ }^{2}$ \\ Agustín Romero $^{2}$ Fernando Dutra ${ }^{2}$
}

${ }^{1}$ Centro Universitario Regional Este, Universidad de la República, Treinta y Tres (33000), Uruguay. E-mail: garciajuanagustin89@gmail.com. *Corresponding author.

2DILAVE “Miguel C Rubino" Regional Este, Treinta y Tres, Uruguay.

\begin{abstract}
In this study, the epidemiological and pathological features of an outbreak of squamous cell carcinoma (SCC) in adult female sheep and a young ram, Friesian Milchschaf breed or crossbreed is described. Seven adult females belonging to an original flock nucleus of 20 animals were affected, as well as a young ram belonging to the same nucleus was affected in other establishment. Multiple verrucous neoplastic masses of several months of evolution were evident in the head region, with local invasion and regional lymph node metastases. Histological studies revealed a cancerous stage of invasion of the dermis and neoplastic proliferation characteristic of invasive SCC, and a pre-cancerous stage with solar elastosis and chronic solar keratosis lesions induced by sunlight. Decrease in latitude, increased level of solar radiation with long exposure to sunlight, and the phenotypic characteristics of the breed are the main factors responsible for the high prevalence of SCC, showing the susceptibility of the Friesian Milchschaf breed and crossbreed in temperate zones as Uruguay.
\end{abstract}

Key words: carcinoma, sunlight radiation, solar keratosis, solar elastosis, small ruminants, skin cancer.

Ocorrência do carcinoma de células escamosas em ovinos Milchschaf em Uruguai

RESUMO: Neste estudo descrevem-se as características epidemiológicas e patológicas de um surto de carcinoma de células escamosas (SCC) em ovelhas adultas e ram jovem, raça Friesian Milchschaf ou cruza. Foram afetadas sete fêmeas adultas pertencentes a um núcleo de rebanho original de 20 animais, bem como um ram jovem pertencente ao mesmo núcleo em que foi afetado em outro estabelecimento. Múltiplas neoplásicas verrucosas de vários meses de evolução foram evidentes na região principal, com invasão local e metástases de linfonodos regionais. Estudos histológicos revelaram um estágio cancerígeno de invasão da derme e proliferação neoplásica característica do SCC invasivo e um estágio pré-cancerígeno com elastose solar e lesões de ceratose solar crônica induzidas pela luz solar. A diminuição da latitude, o aumento do nível de radiação solar com longa exposição à luz solar e as características fenotipicas da raça são os principais fatores responsáveis pela alta prevalência de SCC, mostrando a susceptibilidade da raça Friesian Milchschaf e cruzada em zonas temperadas como o Uruguai.

Palavras-chave: carcinoma, radiação solar, queratose solar, elastose solar, pequenos ruminantes, cancro da pele.

\section{INTRODUCTION}

Cutaneous squamous cell carcinoma (SCC) is a malignant neoplasia of epidermal cells, locally invasive and destructive; although, with low metastatic potential (GROSS et al., 2005; MAULDIN \& KENNEDY, 2016). SCC occurs most frequently in sun-damaged skin and is usually preceded by solar keratosis and carcinoma in situ (GROSS et al., 2005). SCC is common in felines, canines, cattle, horses and humans, less common in sheep, and rare in pigs and goats (MAULDIN
\& KENNEDY, 2016). This neoplasia has been reported in different breeds of sheep, such as Merino, Polwarth, Ile de France and Corriedale, among others (TUSTIN et al., 1982; RAMOS et al., 2007). Lesions can be reported in any part of the body but usually appear on areas of the skin with a lack of pigment or wool. In sheep, the tumor occurs most frequently on the muzzle, lips, eyelids, pinnae, perineum and vulva (MAULDIN \& KENNEDY, 2016; MACEDO et al., 2008). While SCC in animals and humans is global in occurrence, differences in its distribution in various areas of 
the world have been observed (NEWTON, 1996; BRONDEN et al., 2007; QURESHI et al., 2008). The incidence rate of SCC varies geographically, and is highest in the southern hemisphere and with decreasing latitude, i.e. with higher levels of ultraviolet (UV) radiation (ENTWISTLET, 1977; GOLDSCHMIDT \& HENDRICK, 2002; TSUJITA $\&$ PLUMMER, 2010). The rate of SCC appearance increases by $50 \%$ for each $8-10^{\circ}$ decline in latitude, equivalent to an increase in $29 \%$ per unit of UV exposure (NEWTON et al., 1996; DIEPGEN \&.MAHLER, 2002).

Of several factors associated with the development of SCC, sunlight is the most important carcinogenic stimulus for these tumors. It is related to over expression of $\mathrm{p} 53$ protein as a result of UVinduced mutations of the p53 tumor suppressor gene (BRASH et al., 1991). At the same time, the risk of developing SCC is higher in females and increases linearly with the age of the animal (LADDS \& ENTWISTLET et al., 1977; GOLDSCHMIDT \& HENDRICK, 2002). Other possible factors associated with SCC development are infections with Papillomavirus (VITIELLO et al., 2017) and traumatic lesions, like caravan wounds and tattoos (LADDS \& ENTWISTLET et al., 1977; GOLDSCHMIDT \& HENDRICK, 2002).

The Friesian Milchschaf is a dairy sheep breed originally from eastern Friesland, a coastal region in northern Germany (latitude $53^{\circ} \mathrm{N}$ ). It is a prolific ovine biotype, with high maternal ability and lambs with a high growth rate. Phenotypically it is characterized by white skin, and head and legs clear of wool. In recent decades, different countries of South America such as Argentina and Uruguay have introduced the breed to improve sheep production (KREMER \& ROSÉS, 2016). In Argentina it was introduced in 1960's for meat production due to its prolificacy, and further, in 1980, it was used for milk production due to the increasing demand for dairy products and by-products of small ruminants, then introduced to Uruguay in 1990 in order to improve the low reproductive indexes and increase the competitiveness of small sheep producers (BARBATO et al. 2011; BARRIOS et al., 2014). This aroused interest in other South American countries such as Brazil, towards which exports have been made since 2007 for milk production purpose as a sustainable alternative to improve the quality of life of small rural producers (CORREA et al. 2006).

The present study describes outbreaks of SCC in sheep of the Milchschaf breed and crossbreeds.
Different pre-cancerous and cancerous stages were registered pathologically, as well as epidemiological characteristics, showing solar radiation as the main factor associated with tumor induction.

\section{MATERIALS AND METHODS}

The outbreaks occurred in the summer's of 2014 and 2015 (December-February) on mixed sheep and cattle farms situated in the $7^{\text {th }}$ and $11^{\text {th }}$ counties, Treinta and Tres department (latitude: $33^{\circ} 18^{\prime} \mathrm{S}$; longitude: $54^{\circ} 94^{\prime} \mathrm{W}$ ), Eastern Uruguay. Clinical, epidemiological and management data were collected during visits to the farms. Postmortem examinations and complete histologic evaluations were performed on two affected sheep (cases 1 and 2) following euthanasia with intravenous (IV) sodium pentobarbital and exsanguination. Tissue samples, including different parts of the tumors, regional lymph nodes and sun-exposed skin, were fixed in $4 \%$ buffered formaldehyde, processed routinely, and $5 \mu \mathrm{m}$ sections were cut and stained with Mayer's hematoxylin and eosin (HE) for histology.

\section{RESULTS}

Seven adult female ewes, all five years old, of a flock of 175 pure breed Friesian Milchschaf and crossbreed 3/4 Friesian Milchschaf x 1/4 Finnish Landrace were affected in the first outbreak (case 1). All affected ewes belonged to the primary genetic nucleus flock integrated with 20 animals, resulting in $35 \%$ specific morbidity $(7 / 20)$ and $15 \%$ lethality $(3 / 7)$. They showed multiple papillomatous and verrucous growths of variable size on the face, i.e. lips, mouth corner, nostrils, eyelids and pinna. All the animals were grazed in a large paddock with native pasture, open all year. The second outbreak corresponded to a two-year-old ram (case 2), a crossbred 5/8 Milchschaf x Finnish 3/8, of a 50 flock of the Corriedale breed. The ram, originally belonging to the sheep nucleus of case 1, was acquired from a small sheep producer to improve reproductive rates. It was the only affected animal in the flock.

The necropsied ewe of case 1 presented poor body condition and weakness, with multiple cauliflower-like neoplastic developments of verrucous aspect with a broader base and multifocal crusted patches of variable size in the head region: mouth corner, hard palate, nostrils, eyelids, ear and submandibular region (Figure 1). On the dorsal pinna, 


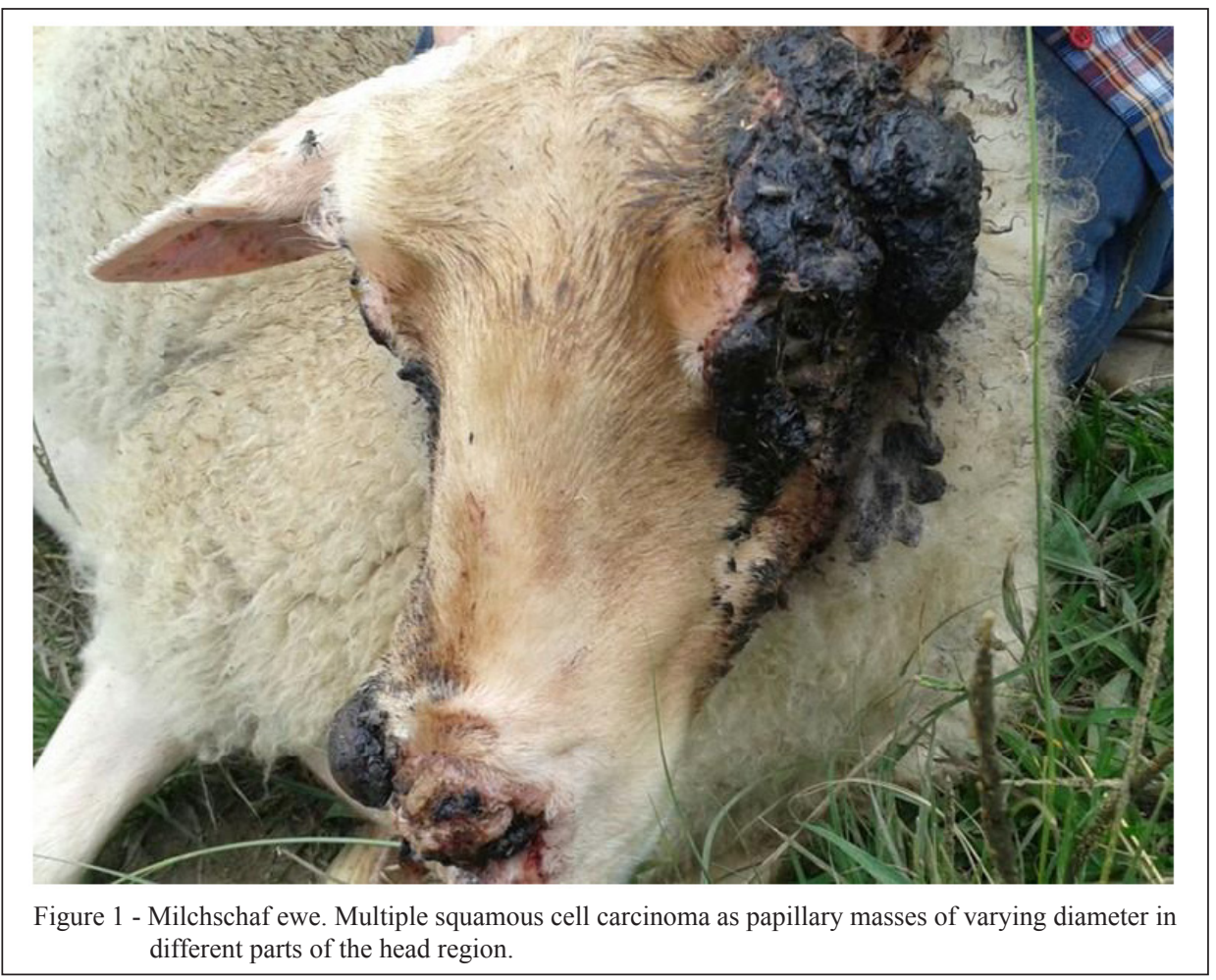

there were texture changes at palpation, rougher and firm, with alopecia, scaling and crusting, and multiple plaque-like lesions of up to $0.5 \mathrm{~cm}$, lesions compatible with solar dermatitis (Figure 2). The young ram of case 2 presented poor body condition, weakness and apathy, with a large verrucous neoplastic mass which destroyed the left orbital region, the eyeball, face, cheek and forehead. The dorsal pinna and cranial face of forelimbs evidenced lesions of solar dermatitis, with erythema and alopecia, and multiple plaque-like crusts of variable diameter up to $1 \mathrm{~cm}$. On cut sections, the tumor masses of both animals were white and firm, with hemorrhagic areas and a crusting necrotic surface in the periphery. Metastasis, characterized by well-delimited masses of firm consistency, was observed in the submandibular and retropharyngeal lymph nodes. Neoplastic invasion to the nostrils and oral cavity was observed in case 1, whereas in case 2, tumor invasion of the skull destroyed the left parietal region, zygomatic arc and orbital fossa.

Microscopically, both cases presented characteristic lesions of invasive SCC, with dermis invasion and neoplastic proliferation and infiltration, from the surface layer of the epidermis, characterized by irregular sized trabeculae, cords and islands of invasive squamous epithelial cells
(Figure 3). Cytologically, neoplastic squamous cells were pleomorphic, with vesicular to round large nuclei, dense chromatin, and 1 or more prominent nucleoli. Also, the neoplastic cells presented prominent intercellular bridges with variable degree of keratinization, either individual cell dyskeratosis or in clusters (Figure 3 inset). Formation of central accumulations of compact laminated keratin (keratin pearls) within islands of invasive neoplastic epithelial cells was observed. There was fibrosis surrounding neoplastic islands, and high mitotic activity as well as mitotic atypia ( 3 to 5 per field $400 x$ ).

Contralateral ear in both cases and the forelimbs of case 2 had lesions of chronic solar dermatitis with pale staining bands of degenerated collagen along subepidermis, and the presence of few typical apoptotic keratinocytes, the so-called "sunburn cells", in the basal and stratum spinosum (Figure 4 inset). Some areas showed lesions of solar keratosis with epidermal hyperplasia and dysplasia (rete pegs), orthohyperkeratosis, lichenoid subepidermal lymphoplasmocytic infiltrate, and pale-staining band of collagen along subepidermis (Figure 4). In some areas, the lesions developed into carcinomas in situ, manifested by 


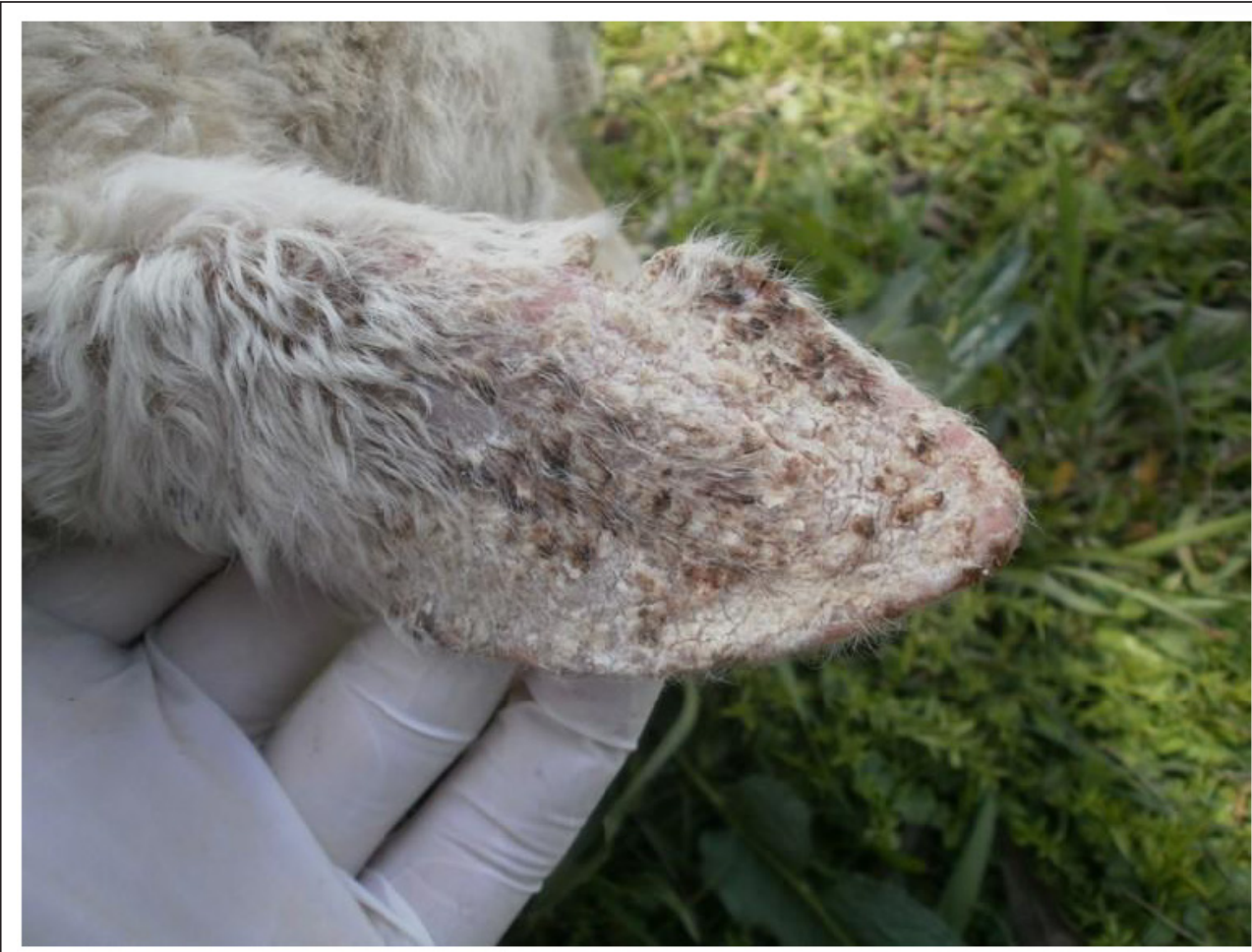

Figure 2 - Milchschaf, ewe. Solar dermatitis lesions with rough and firm texture, alopecia, crusted patches, and multiple plaque lesions in dorsal pinna.

full-thickness epidermal dysplasia, loss of cell polarity, marked nuclear atypia, individual cell apoptosis, and disruption of normal epithelial stratification. No neoplastic lesions were evident in other regions.

\section{DISCUSSION AND CONCLUSION}

A diagnosis of SCC was made based on clinical history, epidemiological data and pathological findings. The study indicated the high susceptibility of the Friesian Milchschaf breed to SCC under these environmental, sanitary and management conditions, possibly due to factors, such as white skin and absence of wool on the head and legs, with high levels of solar radiation causing chronic solar dermatitis.

A high incidence of the disease was evident in adult females; however, the case in a young male highlighted the high susceptibility of the breed under the conditions present in Uruguay. Pathological findings of solar dermatitis and keratosis with inflammatory and degenerative epithelial changes induced by solar radiation indicated a pre- cancerous stage. These lesions frequently progress to invasive SCC (GROSS et al., 2005; TSUJITA \& PLUMMER, 2010), suggesting solar radiation as the main factor predisposing to neoplastic invasion in these outbreaks.

The affected breed, Friesian Milchschaf, is originally from the north of Germany $\left(53^{\circ} \mathrm{N}\right)$ where solar radiation, UV and the risk of skin tumors are much less frequent than in Uruguay $\left(33^{\circ} \mathrm{S}\right)$ (GOLDSCHMIDT \& HENDRICK, 2002; TSUJITA \& PLUMMER, 2010). In Europe, the incidence of SCC or other skin tumors related to $\mathrm{UV}$ radiation are moderate, and tend to decrease in northern parts with higher latitudes (MOAN \& DAHLBACK, 1992; LEITER \& GARBER, 2008). This difference in the rate associated with geographical zones is well studied in humans, and southern hemisphere countries show higher rates of presentation, i.e. more than double compared to latitudes of $37^{\circ}$ to $29^{\circ}$ in Australia (GILES et al., 1988), and increases in $39 \%$ for each $10^{\circ}$ decrease in latitude in Africa (NEWTON et al., 1996). In cattle, studies have reported a higher incidence of ocular SCC in the south-western hemisphere 


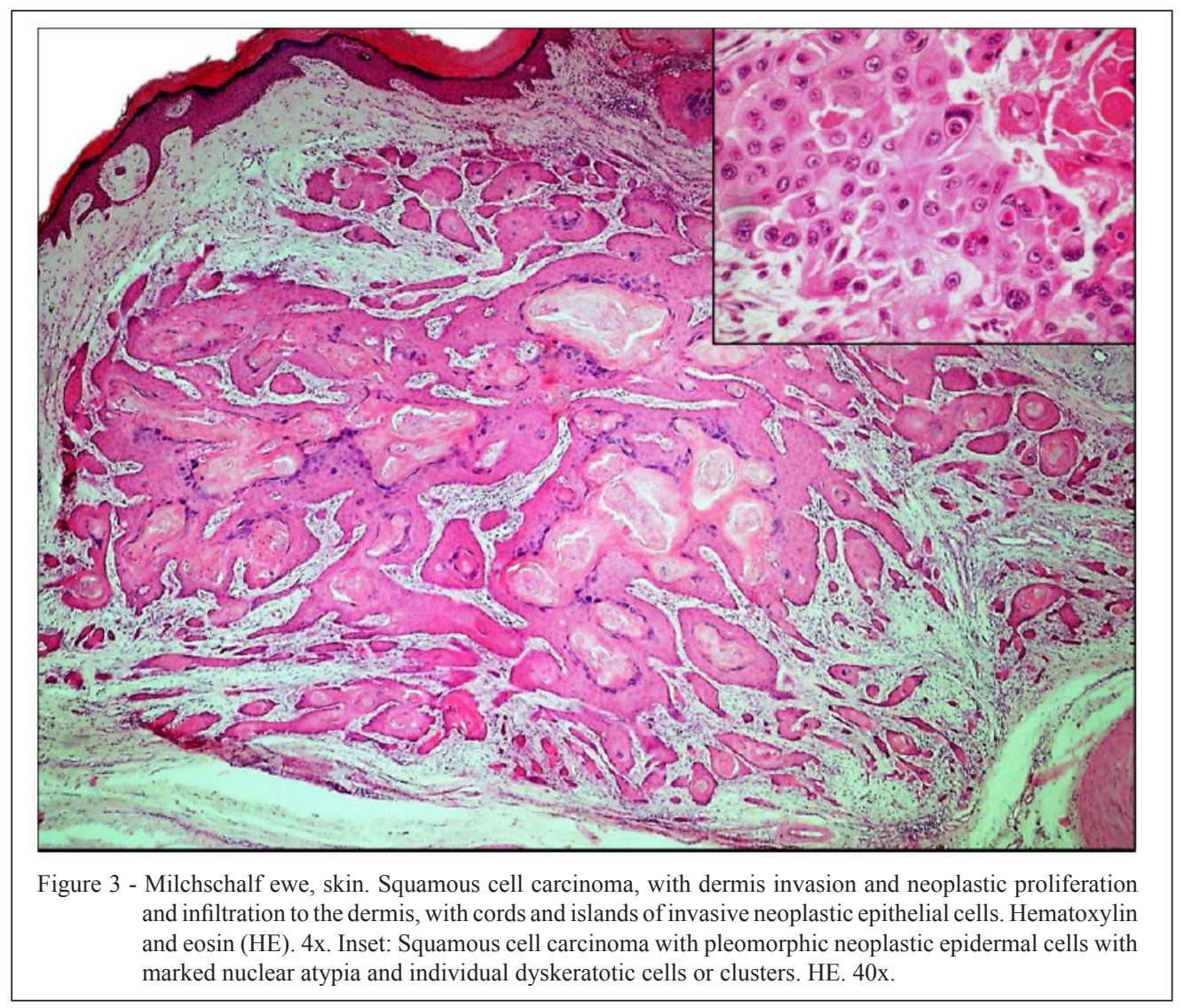

at lower latitudes with higher levels of sunlight (TSUJITA \& PLUMMER, 2010; PUGLIESE et al., 2014). This increased risk associated with extensive farming conditions in our region along with long periods of sunlight exposure and high solar radiation results in a high carcinogenic risk for animals (CARVAHLO et al., 2012). These environmental factors are most common in animals presenting with SCC (MAULDIN \& KENNEDY, 2016). The finding of regional metastases in lymph nodes is rare (GROSS et al., 2005) and showed the high degree of malignancy in SCC.

Though the presence of papillomavirus was not fully investigated, the high incidence of SCC in the present study suggested it might be involved. However, the location of the carcinomas exclusively in skin with no pigmentation and unprotected by wool, the high incidence recorded exclusively in sheep of the same nucleus or genetic line, and the summer occurrence of the disease, suggested that the major causative factor was prolonged exposure to UV radiation in a highly susceptible breed. The importance of papillomavirus as a causal agent of the SCC in sheep should be further investigated (DEL FAVA et al., 2001).

We concluded that a decrease in latitude, increased level of solar radiation with long periods of exposure to sunlight, and the phenotypic characteristics of the introduced breed are the main factors responsible for the high prevalence of SCC under our conditions. Occurrence of SCC in this breed introduced onto commercial farms of Uruguay showed the need to maintain surveillance with periodic clinical inspection of the animals in order to ensure early detection of incipient tumors and surgical removal. The breed is probably inappropriate for the environmental conditions of South America, both in Brazil and Uruguay, being necessary to implement alternatives as to provide shade or forests or genetic selection of more resistant animals, considering that the development of this carcinoma is highly heritable in most species (GOLDSCHMIDT \& HENDRICK, 2002). Further investigations are needed to determine the epidemiology and geographical distribution of $\mathrm{SCC}$ in sheep in the region. 


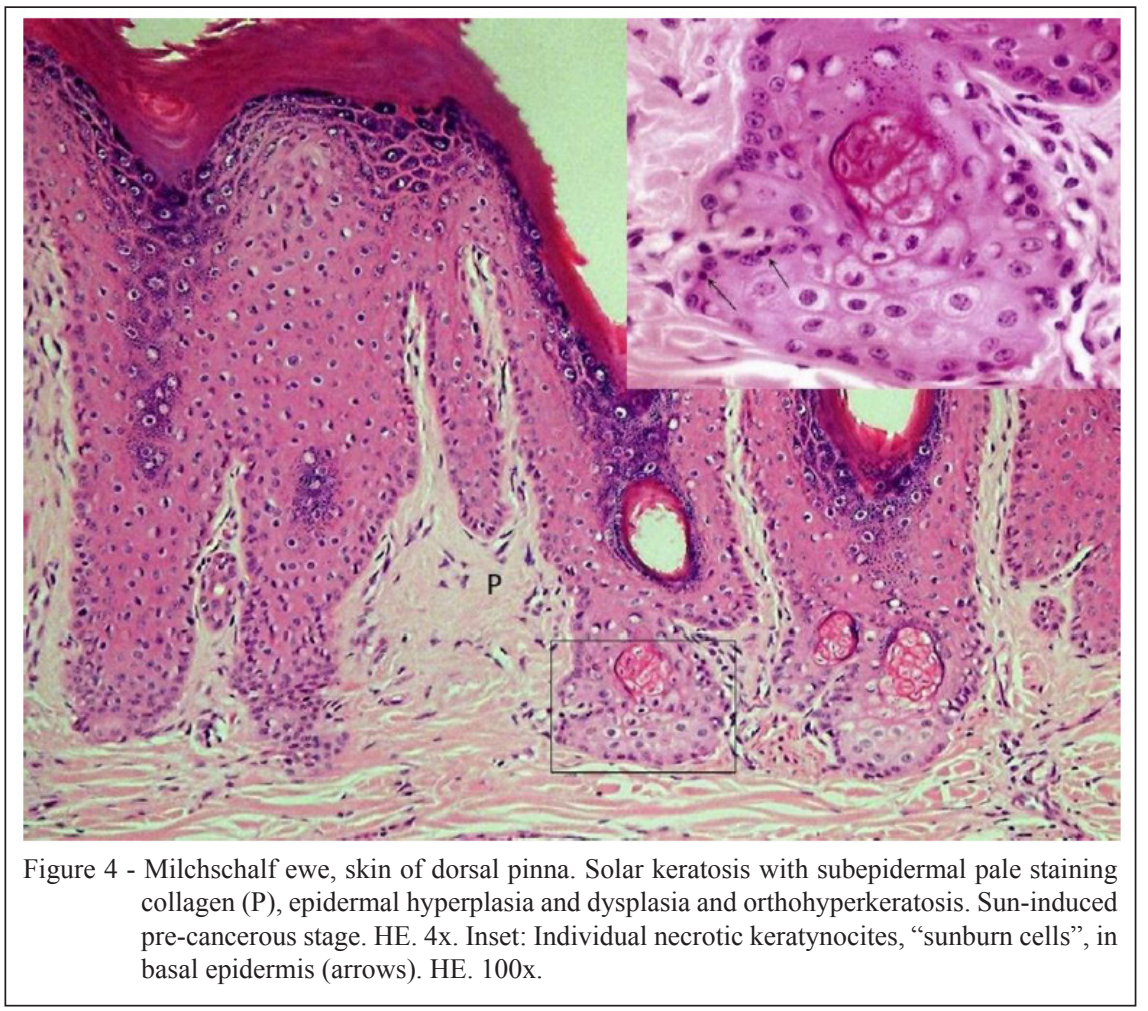

\section{ACKNOWLEDGMENTS}

We thank our colleague Zacarías Pacheco and the technician Ethel Barrios for submitting the animals assessed in the study. We also thank the technician Leticia Ferreira who processed the samples for histology.

\section{COMPLIANCE WITH ETHICAL STANDARDS}

This study was carried out according to the recommendations of the Uruguayan Honorary Commission of Animal Experimentation (CHEA).

\section{CONFLICT OF INTEREST}

The authors declare that they have no conflicts of interest.

\section{REFERENCES}

BARBATO, G. Producción de ovejas Corriedale y cruzas F1 con Milchschaf y Texel en condiciones de pastoreo. Veterinaria (Montevideo), v.47 (181), p9-13, 2011. Available from: <http://www. revistasmvu.com.uy/revistas/numero181.pdf $>$.

BARRIOS, E. et al. Evaluación del potencial productivo de biotipos ovinos prolíficos en la región este. Revista INIA, v.39, p.28-33, 2014. Available from: <http://www.ainfo.inia.uy/digital/ bitstream/item/3912/1/Rev.INIA-2014-No39-p.28-33.pdf>.
BRASH, D.E. et al. Role for sunlight in skin cancer: UV-induced p53 mutations in squamous cell carcinoma. Proceedings of the National Academy of Sciences USA, v.88, p.10124-10128, 1991. Available from: $<$ https://doi.org/10.1073/pnas.88.22.10124>.

BRONDEN, L.B. et al. Veterinary cancer registries in companion animal cancer: a review. Veterinary and Comparative Oncology, Cap.5, v.3, p.133-144, 2007. Available from: $<$ https://doi.org/10.111 $1 / \mathrm{j} .1476-5829.2007 .00126 . \mathrm{x}>$.

CARVAHLO, F.K.L. et al. Risk factors associated with the occurrence of squamous cell carcinoma in ruminants and horses in the semi-arid region of Paraíba. Pesquisa Veterinária Brasileira, Cap.32, v.9, p.881-886, 2012. Available from: <https://doi. org/10.1590/s0100-736x2012000900012>.

CORREA, G.F. et al. Milk production and chemical composition of different sheep genotypes. Ciência Rural, v.36, n.3, p.936941, 2006. Available from: <https://doi.org/10.1590/s0103$84782006000300032>$.

DEL FAVA, C. et al. Occurrence of squamous cell carcinoma in sheep from a farm in São Paulo state, Brazil. Arquivos do Instituto Biológico, v.68, n.1, p.35-40, 2001. Available from: $<$ https://pdfs.semanticscholar.org/97aa/7d9897f102dae66c2fed0fa 46db076469948.pdf>.

DIEPGEN, T.L.; MAHLER V. The epidemiology of skin cancer. British Journal of Dermatology, Cap. 146, v.61, p.1-6, 2002. Available from: doi/10.1046/j.1365-2133.146.s61.2.x/full. 
GILES, G., et al. Incidence of non-melanocytic skin cancer treated in Australia. British Medical Journal, v.269, p.13-7, 1988. Available from: https://doi.org/10.1136/bmj.296.6614.13.

GOLDSCHMIDT, M.H.; HENDRICK, M.J. Tumors of the Skin and Soft Tissues. In: MEUTEN DJ (Ed.), Tumors in domestic animals. Ames: Iowa State Press, p.45-118, 2002.

GROSS, T.L. et al. Neoplasms and other tumors: Epithellial neoplasms and other tumors. In: GROSS TL (Ed.), Skin diseases of the dog and cat. Oxford : Blackwell Science, UK, p.581-589, 2005.

KREMER, R.; ROSÉS, L. Production and composition of milk of Milchschaf(East Friesian) sheep, milked 1 vs 2 times a day. Veterinaria (Montevideo), Cap.52, v.204, p.22-28, 2016. Available from: <http:/ www.revistasmvu.com.uy/revistas/revista204/RevistaVET-Oct-DicKremer.pdf $>$.

LADDS, P.W.; ENTWISTLET, K.W. Observation on squamous cell carcinomas of sheep in Queensland, Australia. British Journal of Cancer, v.35, p.110-114, 1977. Available from: <https://doi. org/10.1038/bjc.1977.10>.

LEITER, U.; GARBER, C. Epidemiology of melanoma and nonmelanoma skin cancer - the role of sunlight. Advances in Experimental Medicine and Biology, v.624, p.89-103, 2008. Available from: $<$ https:// doi.org/10.1007/978-0-387-77574-6_8>.

MACEDO, J. Diseases of the skin in sheep and goats from the Brazilian semiarid. Pesquisa Veterinária Brasileira, Cap.28, v.12,p.633-642, 2008 Available from: $<$ https://doi.org/10.1590/s0100-736x2008001200013>.

MAULDIN, E.A.; KENNEDY, J.P. Integumentary system. In: MAXIE MG (Ed.), Jubb, Kennedy and Palmer's Pathology of domestic animals., $6^{\text {th }}$ ed. Elsevier, v. 1, p.712-714, 2016.
MOAN, J.; DAHLBACK, A. The relationship between skin cancers, solar radiation and ozone depletion. British Journal of Cancer, v.65, p.916-921, 1992. Available from: <https://doi.org/10.1038/ bjc. 1992.192>.

NEWTON, R. et al. Effect of ambient solar ultraviolet radiation on incidence of squamous-cell carcinoma of the eye. Lancet, v.347, p.1450-1451, 1996. Available from: <https://doi.org/10.1016/ s0140-6736(96)91685-2>.

PUGLIESE, M. et al. Bovine ocular squamous cellular carcinoma: a report of cases from the Caltagirone area, Italy. Veterinarski Arhiv, Cap.84, v.5, p.449-457, 2014. Available from: https://pdfs.semanticscholar.org/0c20/3 b84fab9a73ad6d0696682e9112b77c07818.pdf.

QURESHI, A.A. et al. Geographic variation and risk of skin cancer in US women. Archives of Internal Medicine, Cap.168, v.5, 2008. Available from: https://doi.org/10.1001/archinte.168.5.501.

RAMOS, A.T. et al. Squamous cell carcinoma in cattle, sheep and horses: a study of 50 cases in southern Rio Grande do Sul. Brazilian Journal of Veterinary Research and Animal Science, v.44, p.5-13, 2007. Available from: https://doi.org/10.11606/ issn.1678-4456.bjvras.2007.26583.

TSUJITA, H.; PLUMMER, C.E. Bovine ocular squamous cell carcinoma. Veterinary clinics food animal, v.26, p.511-529, 2010.

TUSTIN, R.C. et al. High incidence of squamous cell carcinoma of the vulva in Merino ewes on a South African farm. Journal of the South African Veterinary Association, Cap.53, v.3, p.141-143, 1982.

VITIELLO, V. et al. Ovis ariespapillomavirus 3 in ovine cutaneous squamous cell carcinoma. Veterinary Pathology. Available from: doi.org/10.1177/0300985817705171. 